UDC 681.3

DOI: https://doi.org/10.26642/tn-2018-2(82)-241-246

\author{
V.V. Korobiichuk, Ph. D., Assoc.Prof. \\ R.V. Sobolevskyi, Doctor of Technical Sciences, Prof. \\ O.M. Sydorov, postgraduate \\ V.I. Shamrai, Ph. D. \\ V.O. Shlapak, Ph. D., Assoc.Prof. \\ Zhytomyr State Technological University
}

\title{
The influence of moisture on the colour characteristics of natural stone
}

The objects of the research are the facing elements of buildings and architectural monuments. The subject of the study is the process of changing the colour of the decorative stone from moisture. To solve the problems of analyzing the appearance of the surface, it is necessary to form a digital image of the surface of the facing stone and perform its processing by means of modern computer technology. Natural stone darkens in places where there is moisture in the pores. The paper investigated the component L, which is responsible for the lightness in the Lab colour system, the study was conducted on samples with a length of $600 \mathrm{~mm}$ and a width of $300 \mathrm{~mm}$ with a thickness of 24, 25, 31, $32 \mathrm{~mm}$. To determine the humidity of the samples Hydro Condtrol device was used; it is based on the dielcometric method of measuring the humidity. After 100 hours of exposure to moisture at Pokostivsky granodiorite, the reduction of component $L$, which is responsible for the lightness in the Lab colour system, actually stops. There is a directly proportional dependence of the height of moisture rise in the samples of natural stone on their thickness, which is associated with an increase in the number of pores that participate in the liquid transfer process. With increasing duration of exposure to moisture at Pokostivsky granodiorite the moisture of the sample surface increases, which can be predicted in the general case and for different values of the thickness of the samples using analytical expressions. Comparison of intensity of value change of components $L$, which is responsible for the lightness in the Lab colour system and surface moisture of the samples, allows to draw a conclusion about the absence of an explicit connection between the above-mentioned processes.

Keywords: granodiorite; humidity; color of stone; light stone; decorative indexes.

Introduction. Natural stone gives any building its own unique style and noble appearance. Stone-faced house always stands out against the background of neighboring buildings. Various types of natural stone are used for facing the facades of houses. Recently, designers and builders increasingly prefer this unique natural material.

Professionally made granite facade cladding will not only improve the appearance of the house, but also help to solve many practical problems. Due to its physical and chemical properties, this stone is ideal for exterior decoration of houses. In summer, the stone protects the building from sunlight, keeping pleasant cool inside, and protects from rain and sleet in autumn. Natural stone is frost-resistant material, it is not afraid of even the strong winter cold and wind. Houses cladded with sandstone are characterized by high strength and durability. The magnificent appearance of the stone-cladded facade of the building will remain unchanged for many years. The commercial value of such houses is significantly increasing.

Most of the stone products are used outside buildings and structures, which leads to constant contact of the product surface with moisture. This leads to a gradual deterioration of the operational and decorative properties of the stone due to corrosion processes of the stone. There is a gradual darkening of the surface of the product, the appearance of brown and greenish spots. Over time, the stay of facing products under the influence of natural and man-made environment, there is a deterioration of decorative properties with a slight deterioration in the strength properties. A characteristic feature of the Pokostivsky granodiorite (Grey Ukraine) is the change of lightness when wet, which is perceived by the visual analyzer of the person. This is noticeable when facing buildings with natural stone, especially when such works cover a large area [1].

Analysis of the research. Now the definition of decorative indicators [4] is carried out by organoleptic method, which is subjective. There are also objective methods for assessing decorative value, with which it is possible to quantify the standard colourimetric parameters i.e. brightness, saturation of the main tone of colour, wavelength of the main (dominant) colour tone with the help of information and computer technology. Works [59] offer the technique excluding subjective definition of decorative properties of rocks. Works [10, 11] studied the changes of microtexture of the rock-forming minerals by grinding-polishing natural stone using microscopy and spectral analysis on the formation of microtexture of the mineral. Also works $[12,13]$ conducted a study of the properties of natural stone by ultrasonic method.

Works $[14,15]$ investigated the influence of high temperatures on the change of stone properties by digital image processing. It was found that with increasing temperature the stone brightens. Black-and-white digital image processing [16] was used to identify brighten areas on the surface of natural stone in the study of the effect of 
weathering and the action of salts on the stone. According to the work [17] the roughness of the stone during polishing can affect the colour of the stone surface. This work studied the influence of not only polishing, but also the influence of the acidic environment on limestone and marble, which to some extent increases the roughness of the surface of the stone, but these changes are not uniform. At the same time, unlike mechanical polishing, the colour of the stone surface after the influence of the acid medium depends not only on the roughness of the stone surface, but also on the mineral particles that make up the rock. The analysis of literature sources shows that the previous studies are related to the study of the micro-texture of stone [8-11], the influence of various atmospheric and aggressive factors [2, 3, 13], the development of methods for determining the colour coordinates [4, 5], but not enough attention was paid to the study of the influence of moisture and lightness of the natural stone

The aim of the work is to determine the nature of the interaction of facing stone with moisture on the example of the Pokostovsky granodiorite.

Statement of basic material. A characteristic feature of Pokostivsky granodiorite is that it has a different colour. Pokostovsky granodiorite is mined in 5 quarries, which have differences in chemical, mineralogical composition, and also have various impurities that affect its colour. Blue shades are formed due to the presence of extra-fine mineral and gas-liquid inclusions. Potassium feldspar (potash feldspar and plagioclase) provide granitoids with red and pink colours, rarely cream, white and light gray. Plagioclases provide granitoids with white, light grey and grey to black colours, sometimes greenish, yellowish and greyish - green hues (due to the microinclusion of green iron-containing silicates), this is due to secondary changes in plagioclases i.e. the formation of chlorite, epidote. Dark-coloured minerals (biotite, hornblende, pyroxene) do not practically affect the general perception of the colour of granitoids and the rock only get grey or dark grey colour when their amount is $15-20 \%$.

The objects of the research are the facing elements of buildings and architectural monuments. The subject of the study is the process of changing the colour of the decorative stone from moisture. To solve the problems of analyzing the appearance of the surface, it is necessary to form a digital image of the surface of the facing stone and perform its processing by means of modern computer technology. Example of determination of Lab colour coordinates the Mdistones program is shown in Fig. 1.

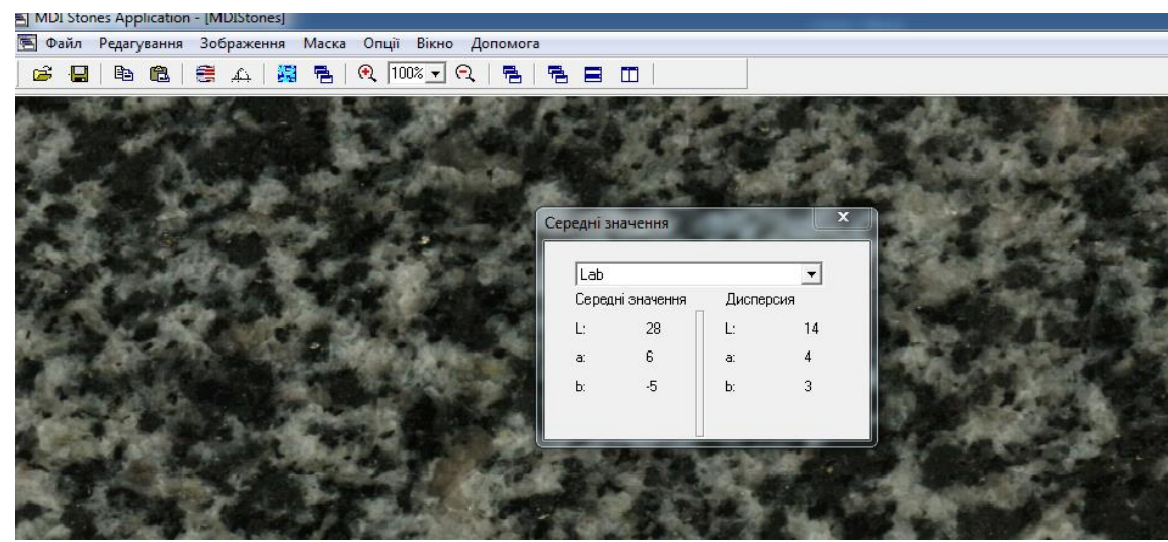

Fig. 1. Image processing of the sample surface in the Mdistones program

The research methodology is as follows:

- plates $300 \times 600 \mathrm{~mm}$ and $20,30 \mathrm{~mm}$ thick are selected;

- the initial data (colour, humidity of natural stone with the help of the dielcometric method) are measured;

- The samples are placed in a water bath;

- measured data (colour, humidity of natural stone with the help of the dielcometric method) are measured;

- the resulting samples are scanned;

- the resulting image is processed in the Mdistones program;

- $\quad$ the average luminosity 1 in the Lab system for each obtained image is determined.

When studying the effect of moisture on the colour characteristics of natural stone, the effect of the thickness of the facing plate on the height of moisture penetration into the sample was studied. For example, in bollards of Pokostivsky granodiorite, which have a size of $800 \mathrm{~mm}$ width, $800 \mathrm{~mm}$ length, $1000 \mathrm{~mm}$ height, throughout the height the colour changes up to $500 \mathrm{~mm}$ due to humidifying stone with natural ground moisture where it stands (Fig. 2). 


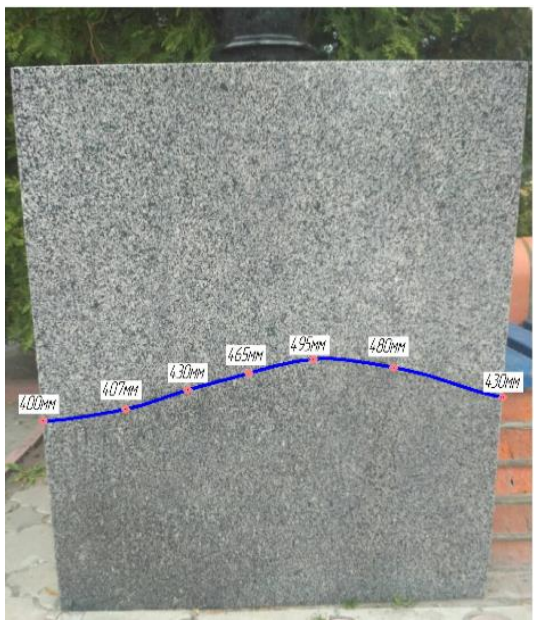

Fig. 2. The stone bollards of Pokostivsky granodiorite, which changed colour due to moisture

The study was carried out on samples with a length of $600 \mathrm{~mm}$ and a width of $300 \mathrm{~mm}$ with a thickness of 24, 25, $31,32 \mathrm{~mm}$. The dependence of the moisture rise in the sample of natural stone on its thickness is shown in Fig. 3.

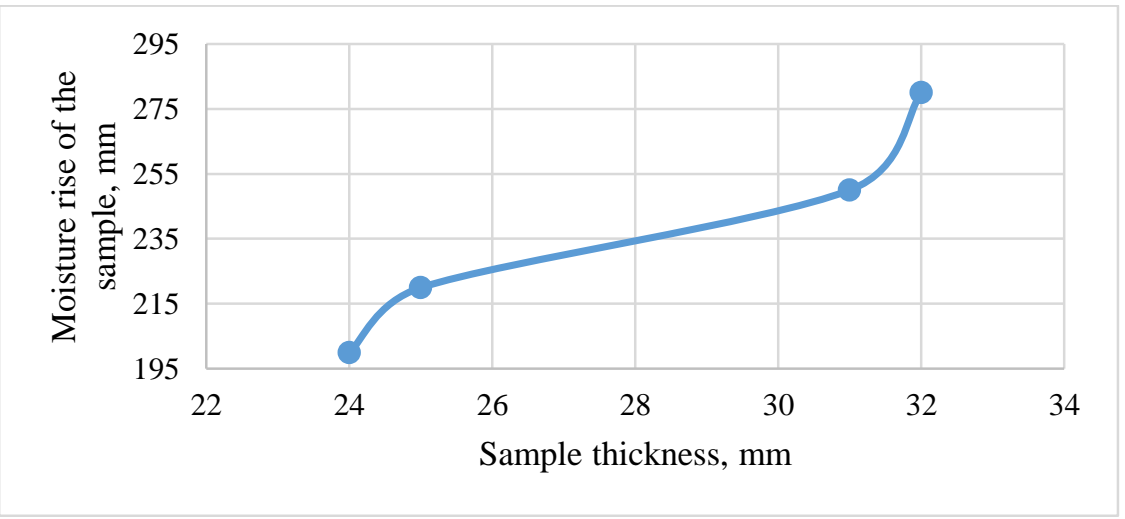

Fig. 3. The dependence of the moisture rise in the sample of natural stone on its thickness

Natural stone darkens in places where there is moisture in the pores The dependence of the component L, which is responsible for the light in the Lab colour system, from the time of exposure of moisture at Pokostivsky granodiorite is shown in the graph, as shown in Fig. 4.

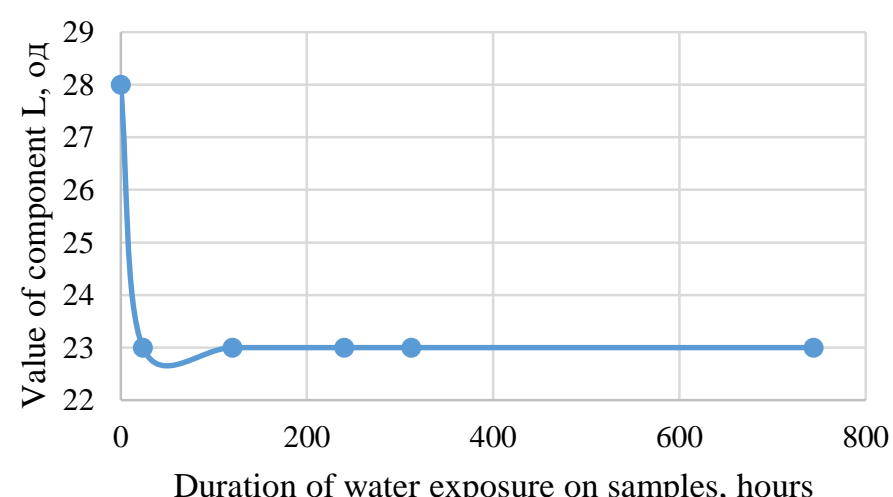

Duration of water exposure on samples, hours
Fig. 4. The dependence of the component $L$, which is responsible for the lightness in the Lab colour system, from the time of exposure of moisture at Pokostivsky granodiorite

To determine the humidity of the samples Hydro Condtrol device was used; it is based on the dielcometric method of measuring the humidity. The measurement was carried out at 12 points on the surface of the sample. The measurement results were averaged (Fig. 5). 


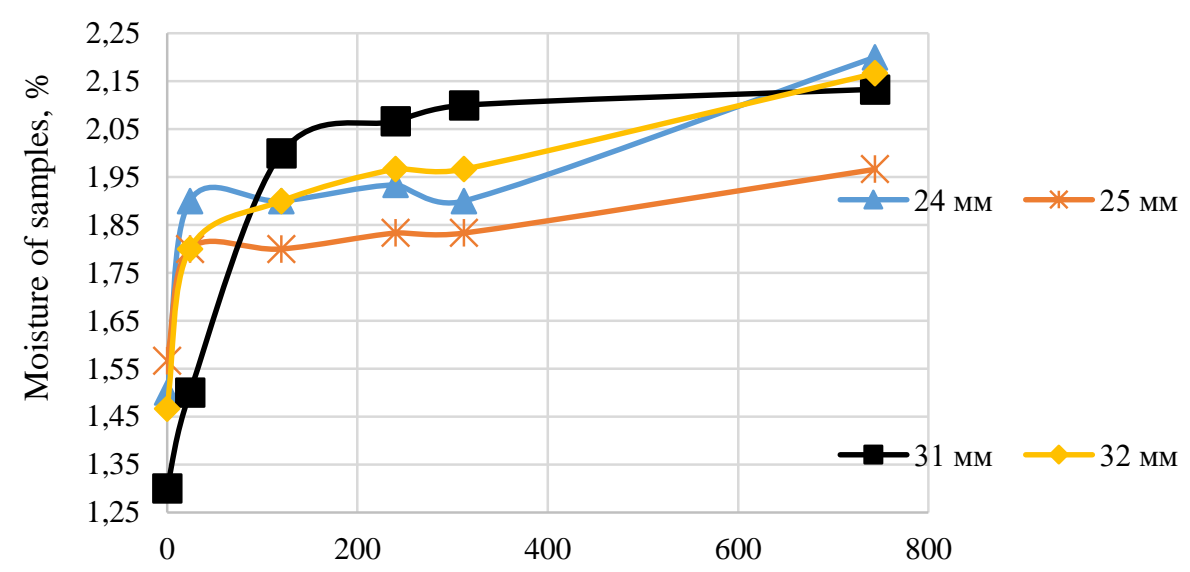

Fig. 5. The dependence of the moisture of stone samples on the dwelling time of these samples in water

Duration of water exposure on samples, hours

In the course of the research of the dependence of the humidity of stone samples on the dwelling time of these samples in water, for samples of different thickness, analytical dependences in the form of polynomials of the second order were established, and they have the following form:

- for $24 \mathrm{~mm}$ thickness

- for $25 \mathrm{~mm}$ thickness

- $\quad$ for $31 \mathrm{~mm}$ thickness

$$
\begin{aligned}
& y=-5 \cdot 10^{-7} x^{2}+0.0011 x+1.6999 \\
& y=-5 \cdot \cdot 10^{-7} x^{2}+0.0008 x+1.6783 \\
& y=-4 \cdot 10^{-6} x^{2}+0.0037 x+1.4077 \\
& y=-x^{2} \cdot 10^{-6}+0.0017 x+1.6281
\end{aligned}
$$

The carried out correlation analysis allowed to establish the presence of a close correlation between the moisture of stone samples and the dwelling time of these samples in water, for all values of the thickness of stone samples, which is characterized by a correlation coefficient of 0.69 (Fig.6).

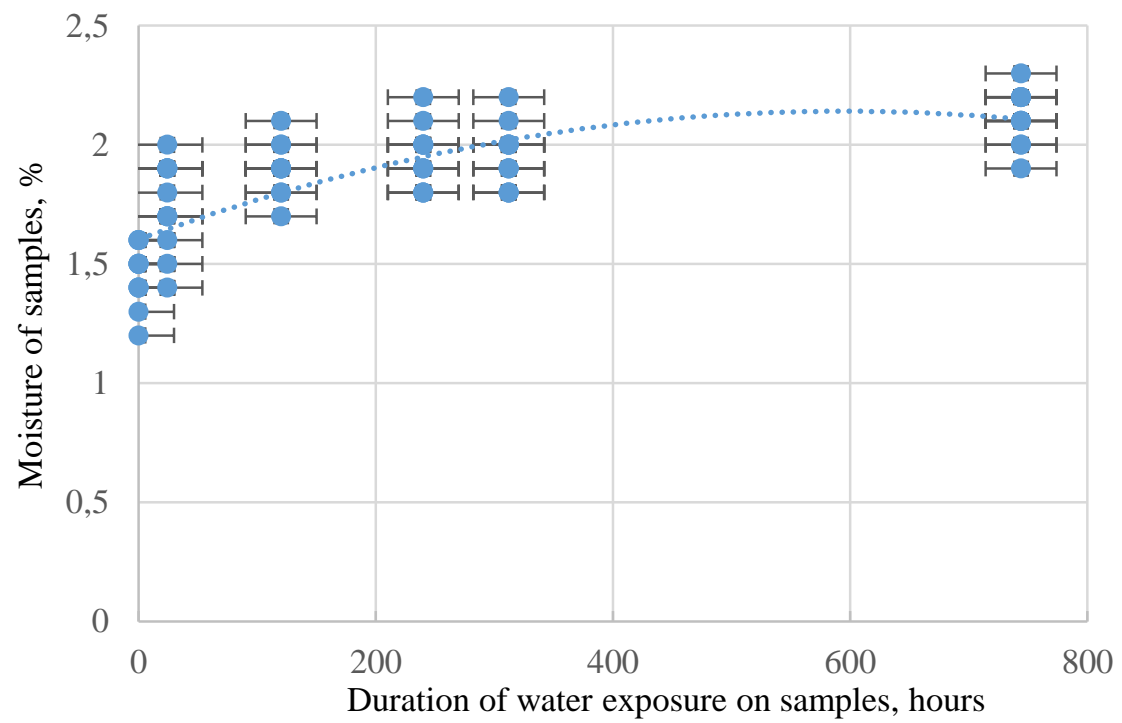

Fig. 6. The dependence of the moisture of stone samples on the dwelling time of these samples in water

Analysis of the above data allows us to conclude that with increasing duration of moisture exposure to Pokostiskyi granodiorite the humidity of the surface of the samples increases, which can be predicted using the expression: $y=-2 \cdot 10^{-6} x^{2}+0.0018 x+1.6035$

Conclusions. After 100 hours of exposure to moisture at Pokostivsky granodiorite, the reduction of component $\mathrm{L}$, which is responsible for the lightness in the Lab colour system, actually stops.

There is a directly proportional dependence of the height of moisture rise in the samples of natural stone on their thickness, which is associated with an increase in the number of pores that participate in the liquid transfer 
process. With increasing duration of exposure to moisture at Pokostivsky granodiorite the moisture of the sample surface increases, which can be predicted in the general case and for different values of the thickness of the samples using analytical expressions.

Comparison of intensity of value change of components L, which is responsible for the lightness in the Lab colour system and surface moisture of the samples, allows to draw a conclusion about the absence of an explicit connection between the above-mentioned processes.

\section{Список використаної літератури:}

1. Коробійчук В.В. Дослідження впливу шліфування-полірування природного каменю на його блиск та відтінки світлоти / В.В. Коробійчук, В.І. Шамрай // СхідноЄвропейський журнал передових технологій. - 2014. № $5 / 5$ (71). - С. 56-60.

2. Криворучко А.О. Дослідження стійкості природного каменю в агресивному середовищі / А.О. Криворучко, B.В. Котенко, О.В. Камських // Вісник КрНУ імені Михайла Остроградського. - 2015. - № 1/1 (90). - С. $133-$ 138.

3. The study of corrosion resistance of Pokostivskiy granodiorites after processing by various chemical and mechanical methods / I.Korobiichuk, V.Korobiychuk, M.Nowicki, V.Shamrai, G.Skyba, R.Szewczyk // Construction \& Building Materials - 2016. - № 114. - Pp. 241-247.

4. Evaluation of the effectiveness of natural stone surface treatment from Ukraine by mechanical and chemical methods / V.Korobiichuk, V.Shamrai, V.Levytskyi, R.Sobolevskyi, O.Sydorov // Rudarsko-geološko-naftni zbornik. - 2018. Vol. 33. - No. 4. - Pp. 15-22.

5. Weakening of rock strength under the action of cyclic dynamic loads / V.Korobiichuk, V.Kravets, R.Sobolevskyi, A.Han, V.Vapnichna // Eastern-European Journal of Enterprise Technologies. - 2018. - Vol. 2/5 (92). - Pp. 20-25.

6. Криворучко A.O. Розробка узагальненої методики геометризації масивів природного каменю $з$ метою отримання комплексної моделі родовища / А.О. Криворучко, В.В. Коробійчук, С.С. Іськов // Вісник ЖДТУ. Серія : Технічні науки. - 2012. - № 4 (63). - С. 190-202.

7. Коробійчук B.B. Оцінка результатів дослідження залежності параметрів пружніх хвиль від тиску в зразках природного декоративного каменю / В.В. Коробійчук // Вісник Нац. технічного ун-ту України «КПІ». Серія : Гірництво. - К. : НТУУ «КПІ»; ЗАТ «Техновибух», 2012. - Вип. 22. - С. 101-105.

8. Толкач О.М. Визначення основних критеріїв якості пірофілітових сланців / О.М. Толкач, Р.В. Соболевський, С.С. Іськов // Вісник ЖДТУ. Серія : Технічні науки. - 2011. - № 2 (57). - С. 170-176.

9. Формування забарвлення декоративного каменю. Ч. 2. Штучне забарвлення кам'яних виробів / С.C. Іськов, А.О. Криворучко, В.В. Коробійчук, Г.М. Ломаков // Вісник ЖДТУ. Серія : Технічні науки. - 2011. - № 1 (56). C. $100-108$.

10. Study of micro-texture and skid resistance change of granite slabs during the polishing with the Aachen Polishing Machine / D.Wang, X.Chen, M.Oeser, H.Stanjek, B.Steinauer // Wear. - 2011. - № 318 (1). - P. 1-11.

11. Evaluation of subsurface damage in GaN substrate induced by mechanical polishing with diamond abrasives / H.Aida, H.Takeda, S.W. Kim, N.Aota, K.Koyama, T.Yamazaki, T.Doi // Applied Surface Science. - 2014. - № 292. - P. 531536.

12. Korobiichuk V. Study of Ultrasonic Characteristics of Ukraine Red Granites at Low Temperatures / V.Korobiichuk // International Conference on Systems, Control and Information Technologies 2016. - Springer International Publishing, 2016. - Pp. 653-658.

13. Investigation of leznikovskiy granite by ultrasonic methods / I.Korobiichuk, V.Korobiichuk, P.Hájek, P.Kokeš, A.Juś, R.Szewczyk // Archives of Mining Sciences. - 2018. - Vol. 63. - No. 1. - C. 75-82.

14. Ozguven A. Investigation of some property changes of natural building stones exposed to fire and high heat / A.Ozguven, Y.Ozcelik // Construction and Building Materials. - 2013. - No. 38. - P. 813-821.

15. Коробійчук В.В. Метод оцінки тиску, що виникає при тепловому розширенні кристалів солей і льоду в порах природного каменю / В.В. Коробійчук // Вісник ЖДТУ. Серія : Технічні науки. - 2011. - No. 3 (58). - С. 176179.

16. Digital image processing of weathered stone caused by efflorescences: A fool for mapping and evaluation of stone decay / M.Vazquez, E.Galan, M.Guerrero, P.Ortiz // Construction and Building Materials. - 2011. - No. 25, Iss. 4. P. 1603-1611.

17. Influence of surface roughness on color changes in building stones / D.Benavente, F.Martínez-Verdú, A.Bernabeu, V.Viqueira, R.Fort, M.García del Cura, S.Ordóñez // Color Research \& Application, - 2003. - No. 28. - Iss. 5. P. 343-351.

\section{References:}

1. Shamrai, V.I. and Korobijchuk, V.V. (2014), «Doslidzhennja vplyvu shlifuvannjapoliruvannja pryrodnogo kamenju na jogo blysk ta vidtinky svitloty», Shidno-Jevropejs'kyj zhurnal peredovyh tehnologij, No. 5/5 (71), Pp. 56-60.

2. Kryvoruchko, A.O., Kotenko, V.V. and Kamskih, O.V. (2015), «Doslidzhennja stijkosti pryrodnogo kamenju v agresyvnomu seredovyshhi», Visnyk KrNU imeni Myhajla Ostrograds'kogo, No. 1/1 (90), Pp. 133-138.

3. Shamrai, V., Korobijchuk, I., Korobiychuk, V., Skyba, G., Nowicki, M. and Szewczyk, R. (2016), «The study of corrosion resistance of Pokostivskiy granodiorites after processing by various chemical and mechanical methods», Construction \& Building Materials, No. 114, Pp. 241-247.

4. Korobiichuk, V., Shamrai, V., Levytskyi, V., Sobolevskyi, R. and Sydorov, O. (2018), «Evaluation of the effectiveness of natural stone surface treatment from Ukraine by mechanical and chemical methods», Rudarskogeološko-naftni zbornik, Vol. 33, No. 42, Pp. 15-22. 
5. Korobiichuk, V., Kravets, V., Sobolevskyi, R., Han, A. and Vapnichna, V. (2018), «Weakening of rock strength under the action of cyclic dynamic loads», Eastern-European Journal of Enterprise Technologies, Vol. $2 / 5$ (92), Pp. 20-25.

6. Krivoruchko, A.A., Korobijchuk, V.V. and Iskov, S.S. (2012), «Rozrobka uzagal'nenoi' metodyky geometryzacii' masyviv pryrodnogo kamenju z metoju otrymannja kompleksnoi' modeli rodovyshha», Visnyk ZhDTU, Serija Tehnichni nauky, Vol. 4 (63), Pp. 190-202.

7. Korobiichuk, V. (2012), «Ocinka rezul'tativ doslidzhennja zalezhnosti parametriv pruzhnih hvyl' vid tysku v zrazkah pryrodnogo dekoratyvnogo kamenju», Visnyk Nac. tehnichnogo un-tu Ukrai'ny «KPI», Serija Girnyctvo, Vol. 22, Pp. 101-105.

8. Tolkach, O.M., Sobolevskyi, R.V. and Iskov, S.S. (2011), «Vyznachennja osnovnyh kryterii'v jakosti pirofilitovyh slanciv», Visnyk ZhDTU, Serija Tehnichni nauky, Vol. 2 (57), Pp. 170-176.

9. Iskov, S.S., Krivoruchko, A.A., Korobijchuk, V.V. and Lomakov, G.N. (2011), «Formuvannja zabarvlennja dekoratyvnogo kamenju. Ch. 2. Shtuchne zabarvlennja kam'janyh vyrobiv», Visnyk ZhDTU, Serija Tehnichni nauky, Vol. 1 (56), Pp. 100-108.

10. Wang, D., Chen, X., Oeser, M., Stanjek, H. and Steinauer, B. (2014), «Study of microtexture and skid resistance change of granite slabs during the polishing with the Aachen Polishing Machine», Wear, No. 318 (1), Pp. 1-11.

11. Aida, H., Takeda, H., Kim, S.W., Aota, N., Koyama, K., Yamazaki, T. and Doi, T. (2014), «Evaluation of subsurface damage in GaN substrate induced by mechanical polishing with diamond abrasives», Applied Surface Science, No. 292, Pp. 531-536.

12. Korobiichuk, V. (2016), «Study of Ultrasonic Characteristics of Ukraine Red Granites at Low Temperatures», International Conference on Systems, Control and Information Technologies, Springer International Publishing, Pp. 653-658.

13. Korobiichuk, I., Korobiichuk, V., Hájek, P., Kokeš, P., Juś, A. And Szewczyk, R. (2018), «Investigation of leznikovskiy granite by ultrasonic methods», Archives of Mining Sciences, Vol. 63, No. 1, Pp. 75-82.

14. Ozguven, A. and Ozcelik, Y. (2013), «Investigation of some property changes of natural building stones exposed to fire and high heat», Construction and Building Materials, No. 38, Pp. 813-821.

15. Korobijchuk, V.V. (2011), «Metod ocinky tysku, shho vynykaje pry teplovomu rozshyrenni krystaliv solej i l'odu v porah pryrodnogo kamenju», Visnyk ZhDTU, Serija Tehnichni nauky, Vol. 3 (58), Pp. 176-179.

16. Vazquez, M., Galan, E., Guerrero, M. and Ortiz, P. (2011), «Digital image processing of weathered stone caused by efflorescences: A tool for mapping and evaluation of stone decay», Construction and Building Materials, No. 25, Vol. 4, Pp. 1603-1611.

17. Benavente, D., Martínez-Verdú, F., Bernabeu, A., Viqueira, V., Fort, R., García del Cura, M. and Ordóñez, S. (2003), «Influence of surface roughness on color changes in building stones», Color Research \& Application, No. 28, Vol. 5, Pp. 343-351.

Коробійчук Валентин Вацлавович - кандидат технічних наук, доцент кафедри розробки родовищ корисних копалин ім. проф. Бакка М.Т. Житомирського державного технологічного університету.

Наукові інтереси:

- обробка природного каменю;

- відкрита розробка родовищ корисних копалин.

Соболевський Руслан Вадимович - доктор технічних наук, професор кафедри маркшейдерії Житомирського державного технологічного університету.

Наукові інтереси:

- маркшейдерія;

- відкрита розробка родовищ корисних копалин.

Сидоров Олександр Миколайович - аспірант асистент кафедри розробки родовищ корисних копалин ім. проф. Бакка М.Т. Житомирського державного технологічного університету.

Наукові інтереси:

- декоративні властивості природного каменю;

- фактурна обробка природного каменю.

Шамрай Володимир Ігорович - кандидат технічних наук, асистент кафедри розробки родовищ корисних копалин ім. проф. Бакка М.Т. Житомирського державного технологічного університету.

Наукові інтереси:

- гірництво;

- фактурна обробка природного каменю.

Шлапак Володимир Олександрович - кандидат технічних наук, доцент кафедри розробки родовищ корисних копалин ім. проф. Бакка М.Т. Житомирського державного технологічного університету.

Наукові інтереси:

- гірництво;

- комп'ютерні технології. 